\title{
Studies on Manurial Quality of Compost Enriched with Rock Phosphate
}

\author{
Kanika Baghla ${ }^{1}$, Jain Praveen Kumar ${ }^{1}$, Chopra Pankaj ${ }^{2}$ and Tammana ${ }^{1}$ \\ ${ }^{1}$ University Institute of Agricultural Sciences, Chandigarh University, Mohali, Punjab, India \\ ${ }^{2}$ (HAREC) CSKHPKV, Palampur Himachal Pradesh 176062, India \\ *Corresponding author
}

\section{A B S T R A C T}

\section{Keywords \\ Animal and plant based organics, Enrichment, \\ Manure quality, Rock phosphate}

\section{Article Info}

Accepted:

15 March 2020 Available Online: 10 April 2020
A study on the manurial quality of enriched organics was conducted in the research farm of CSKHPKV, Palampur (Himachal Pradesh) falling under wet temperate mid hill climatic condition for two years. Two organics namely farmyard manure and compost (prepared from locally available plant biomass comprising of clippings of Lantana camara and Eupatorium spp) were enriched with indigenous Jhamarkotra Phosphate Rock (JPR-A) containing $8.1 \% \mathrm{P}$ in the clay lined pits of $1 \mathrm{~m}^{3}$ size. Organic materials with and without enrichment were analyzed for different parameters after 0,45 and 90 days of decomposition and results have been interpreted on dry weight basis. Organic carbon in the rock phosphate enriched FYM decreased by $26 \%$ after 90 days of decomposition and the respective decrease in enriched compost was $26.5 \%$. Total $\mathrm{N}$ content was higher in compost products. After 90 days of decomposition there was substantial increase in water soluble, citrate soluble and sodium bicarbonate extractable $\mathrm{P}$ in the enriched organics. Total P $(1.54 \%)$ and total $\mathrm{K}(0.76 \%)$ content was higher in enriched compost compared to enriched FYM (total P: $1.36 \%$ and total $\mathrm{K}: 0.70 \%$ ). The reduction in $\mathrm{C}: \mathrm{N}$ ratio was 37 and $39 \%$ in enriched FYM and enriched compost, respectively, whereas reduction in C:P ratio was to the tune of $65 \%$ in enriched material. Thus, enrichment of FYM and Compost with rock phosphate enhanced the manurial value of organics with particular reference to $\mathrm{P}$, in addition to other nutrient elements.

\section{Introduction}

Integrated use of organics has now assumed significance due to intensive farming. In addition to animal based organics, the plant based organics including the biomass of certain weeds vis-à-vis Lantana and Eupatorium available in abundance in certain areas specified as waste lands and areas adjoining to fields may also be composted and put to use. The organic amendments are low in plant nutrients per unit weight so inorganic addition such as rock phosphate can be used for improving their quality through enrichment.

In addition to $\mathrm{P}$ supply, the quality of enriched FYM and compost is also enhanced with respect to $\mathrm{N}, \mathrm{Ca}, \mathrm{Mg}$ and micronutrients as revealed by the findings of Mathur and Devnath (1983). Also C: N and C: P ratios decrease considerably following the 
decomposition of organics with rock phosphate. Availability of $\mathrm{P}$ is low both in high and low $\mathrm{pH}$ soils and under such conditions, enrichment of organics with cheap and indigenously available source as rock phosphate can be exploited. In view of observations cited above, a study on the manurial quality of organics following enrichment with rock phosphate was undertaken.

\section{Materials and Methods}

The present study was undertaken in the experimental farm of Himachal Pradesh Krishi Vishvavidyalaya Palampur falling under mid hill wet temperate zone. Four manurial products were prepared from two organics comprising farmyard manure and compost prepared from locally available plant biomass. The plant biomass included the clippings of Lantana camara and Eupatorium spp. The enrichment of these materials was done with indigenous Jhamarkotra phosphate rock (JPR-A, containing $8.1 \% \mathrm{P}$ ) in the clay lined pits of $1 \mathrm{~m}^{3}$ size.

Calculated amount of rock phosphate was added during filling of pits with organics. For preparation of $100 \mathrm{~kg}$ organic manure on dry weight basis, addition of $3 \mathrm{~kg}$ of JPR-A is required, which enriches the material to about $0.22 \%$ P level. Polythene sheet was spread at the bottom of each pit before filling the material so as to prevent leaching losses. The manurial pits were filled to brim and were covered in a dome shape to prevent excessive wetting of the material by rain water.

The material in the pits was stirred thrice with rakes (during the entire decomposition process) for providing aeration and better mixing of the decomposing material. It took about 90 days for thorough decomposition of the organic materials. The manurial products $\left(\mathrm{P}_{1}-\mathrm{P}_{4}\right)$ are listed in Table 1.
For quality analysis, different manurial products were sampled at initial stage (0 day), 45 days and 90 days of decomposition. Fresh samples of the products were used for $\mathrm{pH}$, ammoniacal-N, nitrate-N, water soluble $\mathrm{P}$, citric acid soluble $\mathrm{P}$ and water soluble $\mathrm{K}$ determination. Standard procedures as described by Black (1965) were followed for analysis of chemical constituents.

\section{Results and Discussion}

The data is averaged for two consecutive years of study and expressed on dry weight basis.

\section{Organic carbon}

The results presented in Figure 1 revealed average carbon content of 30.1 and $28.1 \%$ in the FYM and enriched FYM manurial products after 90 days of decomposition, respectively. The respective per cent decrease in carbon content was 23 and 26 from the original values. The average carbon content of compost $\left(\mathrm{P}_{2}\right.$ product) and enriched compost ( $\mathrm{P}_{4}$ product) reduced to 32.7 and $31.5 \%$ after 90 days of decomposition, respectively with respective decrease of 21 and $26 \%$ from the original value at zero day. In general, there was decrease in the carbon content with increase in time of decomposition and the rate of decomposition was higher in enriched products which may be attributed to enhanced microbial activity in decomposition process resulting in depletion of carbonaceous compounds with lapse of time.

The data further revealed that rate of loss of carbon was higher with P-enrichment which may be due to the increased availability of phosphate as food to microbes involved in the process as well as the increased fungal growth in the presence of phosphate rock, responsible for fast decomposition. 
pH

As revealed by the Figure 1 the initial $\mathrm{pH}$ of manurial products varied between 7.8-8.0 and the respective range of 7.3-7.4 was recorded after 90 days of decomposition. Singh and Amberger (1990) also reported that during organic matter decomposition a number of intermediate compounds including organic acids are produced which render decrease in $\mathrm{pH}$.

Similar findings have been reported by Bhardwaj (1995) who found that optimum $\mathrm{pH}$ for most microorganisms involved in decomposition of organics is between 6.5 and 7.5 .

\section{Total nitrogen}

Total nitrogen content (Fig. 2) varied between 1.40-1.57 and 1.41-1.64 per cent in FYM and enriched FYM at the initial stage and 90 days of decomposition, respectively. The corresponding variation in the compost and enriched compost was 1.47-1.71 and 1.50$1.77 \%$ between the initial stage and final stage (90 days) of decomposition.

The increase in $\mathrm{N}$ in the decomposed products may be due to reduction in mass as well as release of nitrogen after death and decay of microorganisms. Further, it was observed that total $\mathrm{N}$ content was higher in compost products $\left(\mathrm{P}_{2}\right.$ and $\left.\mathrm{P}_{4}\right)$ which may be ascribed to higher $\mathrm{N}$ content of Lantana and Eupatorium biomass.

\section{Phosphorus}

The data in Figure 3 and 4 embody the contents of Water soluble P (WSP), Citric acid soluble $\mathrm{P}$ (CSP), Sodium bicarbonate extractable $\mathrm{P}$, Organic $\mathrm{P}$ and Total $\mathrm{P}$ in the different manurial products.

\section{Water soluble $\mathbf{P}$ (WSP)}

WSP content of different manurial products increased with time and the rate of increase was substantially higher during 0-45 days of decomposition than the phase between 45-90 days (Fig. 3). Bhardwaj (1995) have attributed this to the fact that under appropriate decomposition conditions, maximum increase in microbial number was noticed during initial stage of decomposition which leads to enhanced microbial activity and hence more release of phosphorus.

The results further infer that $\mathrm{P}$ enriched FYM and compost recorded higher values of WSP at all the stages of decomposition. These results confirm the findings of Manna et al., (2003) and this could be attributed to the production of organic acids during decomposition which cause the release of $\mathrm{P}$ through chelation and removal of metal ions from insoluble metal phosphates (Chien,1979).

\section{Citric acid soluble $\mathbf{P}$ (CSP)}

The results revealed that with increase in decomposition period, there was increasing trend in CSP content and enriched manures recorded still higher values (Fig. 3). This may be due to the reason that rock phosphate enriched organics have abundance of $\mathrm{Ca}$ but lacks $\mathrm{Fe}$ and $\mathrm{Al}$. So, $\mathrm{P}$ released during decomposition is re-fixed which is not water soluble but soluble in citric acid and is available to plants as reported by Mishra et al., (2001).

\section{Sodium bicarbonate extractable $\mathbf{P}$ $\left(\mathrm{NaHCO}_{3}-\mathrm{P}\right)$}

$\mathrm{NaHCO}_{3}$ extractable $\mathrm{P}$ also recorded higher values, ranging between $0.256-0.396 \%$ after 90 days of decomposition (Fig. 3). These findings corroborate the results obtained by 
Mishra et al., (1982) and this may be due to the fact that rock phosphate transformation during decomposition leads to its solubilization in $\mathrm{P}$ form, easily extractable by sodium bicarbonate.

\section{Organic P}

The average organic $\mathrm{P}$ values of $0.27,0.50$ and $0.67 \%$ were recorded in enriched FYM at initial stage, 45 days and 90 days of decomposition, respectively (Fig. 4). The corresponding values in the enriched compost $\left(\mathrm{P}_{4}\right)$ were $0.31,0.58$ and $0.70 \%$ respective stages of decomposition. The results are in conformity to the findings of Mathur and Devnath (1983) who further advocated that unlike competition for $\mathrm{P}$ by plants and its fixation by $\mathrm{Al}$ and $\mathrm{Fe}$ ions in the soil system, it is the microbial immobilization of organic $\mathrm{P}$ which dominates during decomposition and bind $\mathrm{P}$ in organic form and with passage of time, organic $\mathrm{P}$ mineralizes slowly to available form.

\section{Total phosphorus}

Average total $\mathrm{P}$ content in the enriched FYM $\left(\mathrm{P}_{3}\right)$ and compost $\left(\mathrm{P}_{4}\right)$ was 1.36 and $1.54 \%$, respectively after 90 days of decomposition (Fig. 4). The increase in total $\mathrm{P}$ may be explained on the basis of proportionate loss of organic matter during decomposition as substantiated by the results of Figure 1 indicating the reduction in organic carbon in the manurial products after 90 days of decomposition. The increase in total $\mathrm{P}$ content could be attributed to the decomposition process during which a substantial organic biomass is catabolized.

\section{Water soluble and total potassium}

As the decomposition progressed, there was increase in water soluble and total $\mathrm{K}$ content of all the manurial products. The increase in total $\mathrm{K}$ content (Fig. 5) over the period of decomposition may be ascribed to the concentration effect and loss of carbon as $\mathrm{CO}_{2}$, which results in lowering the mass of decomposing material.

\section{$\mathrm{C}: \mathrm{N}$ and $\mathrm{C}: \mathrm{P}$ ratio}

The results with respect to $\mathrm{C}: \mathrm{N}$ and $\mathrm{C}: \mathrm{P}$ ratio have been presented in Figure 6. An important parameter of decomposition is the nutrient content available to the microorganisms for growth which is generally measured by the carbon to nitrogen ratio within organics. In the present study it was seen that there was substantial decrease in $\mathrm{C}: \mathrm{N}$ ratio of different organic products with the time lapse of 90 days.

As the decomposition proceeds, the micro flora uses the carbon for energy and nitrogen for cell building. The $\mathrm{C}: \mathrm{N}$ ratio becomes smaller with time, since the nitrogen remains in the system while carbon is released as $\mathrm{CO}_{2}$ (Gaur, 1999). Further, enriched products $\left(\mathrm{P}_{3}\right.$ and $\mathrm{P}_{4}$ ) exhibited more decrease in $\mathrm{C}: \mathrm{N}$ ratio where rock phosphate was added.

The values of $\mathrm{C}$ : $\mathrm{P}$ ratio of different manurial products varied between 53-117 after 90 days of decomposition. Havlin et al., (2003) have reported that proper mineralization of organic $\mathrm{P}$ occur when C:P ratio is below 200 .

In the present study there was substantial reduction in the $\mathrm{C}: \mathrm{P}$ ratio with passage of time and the rate of reduction was greater in rock phosphate enriched products $\left(\mathrm{P}_{3}\right.$ and $\left.\mathrm{P}_{4}\right)$ with 65 per cent reduction.

The organic amendments must contain at least $0.2 \%$ total $\mathrm{P}$ for mineralization to take place and in the present study, the total P content of all products remained higher than $0.2 \%$, thus allowing $\mathrm{P}$ mineralization to occur for $\mathrm{P}$ availability to plants. 
Table.1 Treatments employed for preparation of organics $\left(\mathrm{P}_{1}-\mathrm{P}_{4}\right)$

\begin{tabular}{|c|c|c|}
\hline S No & Organic Product & Material Used \\
\hline 1 & $\mathrm{P}_{1}-\mathrm{FYM}$ & $\begin{array}{l}\text { Organic manure prepared from fresh cowdung, urine and } \\
\text { surface litter as such }\end{array}$ \\
\hline 2 & $\mathrm{P}_{2}$-Compost & $\begin{array}{l}\text { Organic manure prepared from } 50 \% \text { fresh cowdung, urine and } \\
\text { surface litter }+50 \% \text { biomass (Lantana, Eupatorium) }\end{array}$ \\
\hline 3 & $\mathrm{P}_{3}$-Enriched FYM & $\begin{array}{l}\text { Organic manure prepared from fresh cowdung, urine and } \\
\text { surface litter, enriched to } 0.22 \% \text { P level with rock phosphate } \\
\text { (JPR-A) }\end{array}$ \\
\hline 4 & $\mathrm{P}_{4}$-Enriched Compost & $\begin{array}{l}\text { Organic manure prepared from } 50 \% \text { fresh cowdung, urine and } \\
\text { surface litter }+50 \% \text { biomass (Lantana, Eupatorium), enriched } \\
\text { to } 0.22 \% \text { P level with rock phosphate (JPR-A) }\end{array}$ \\
\hline
\end{tabular}

O Day 45 Days 90 Days
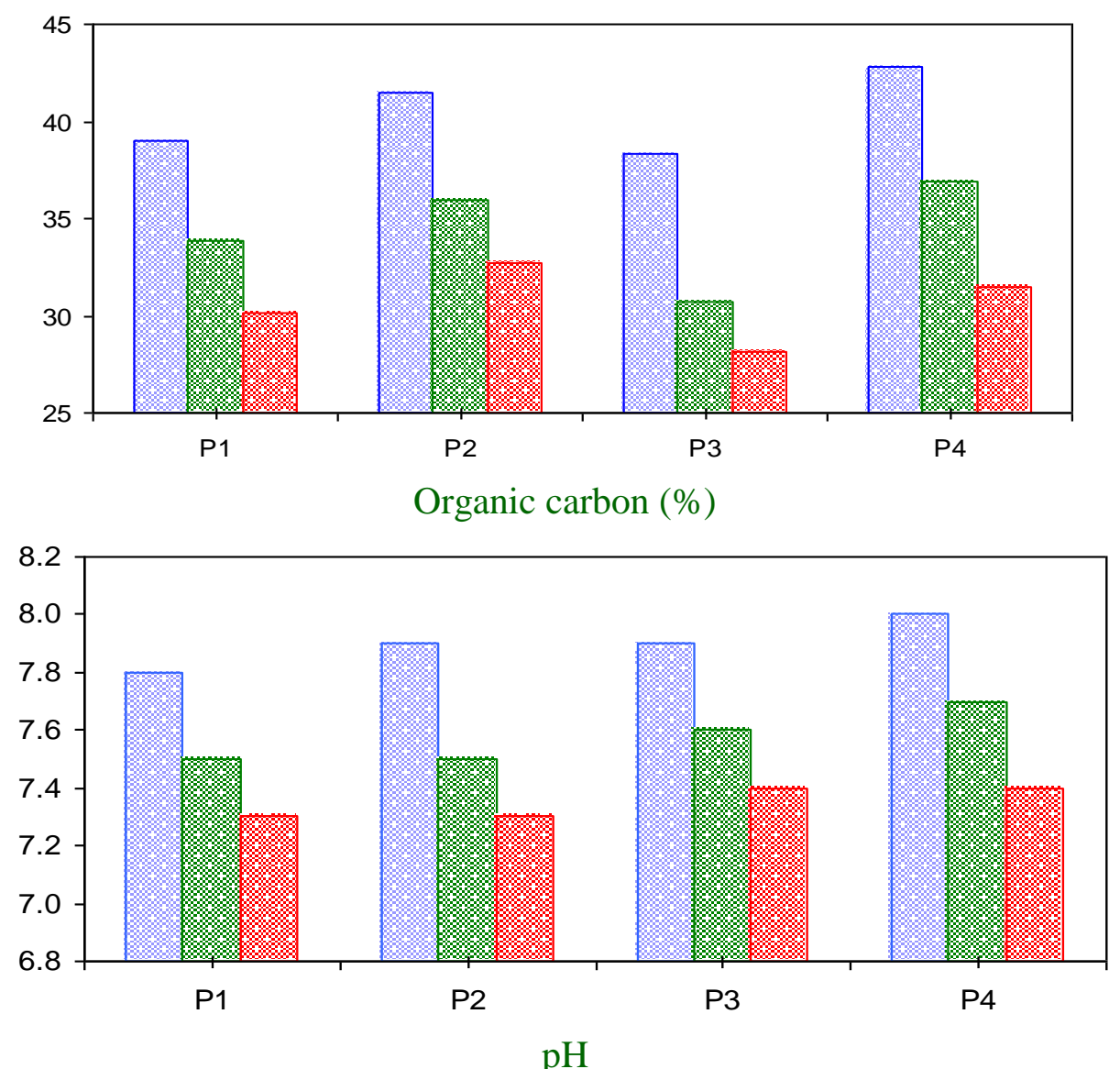

\begin{tabular}{|ll}
\hline PRODUCTS & P2: Compost \\
P1: FYM & P4: P-enriched compost \\
P3: P-enriched FYM &
\end{tabular}

Fig.1 Organic carbon and $\mathrm{pH}$ of organics at different stages of decomposition 


\section{응 Day 945 Days $: 90$ Days}

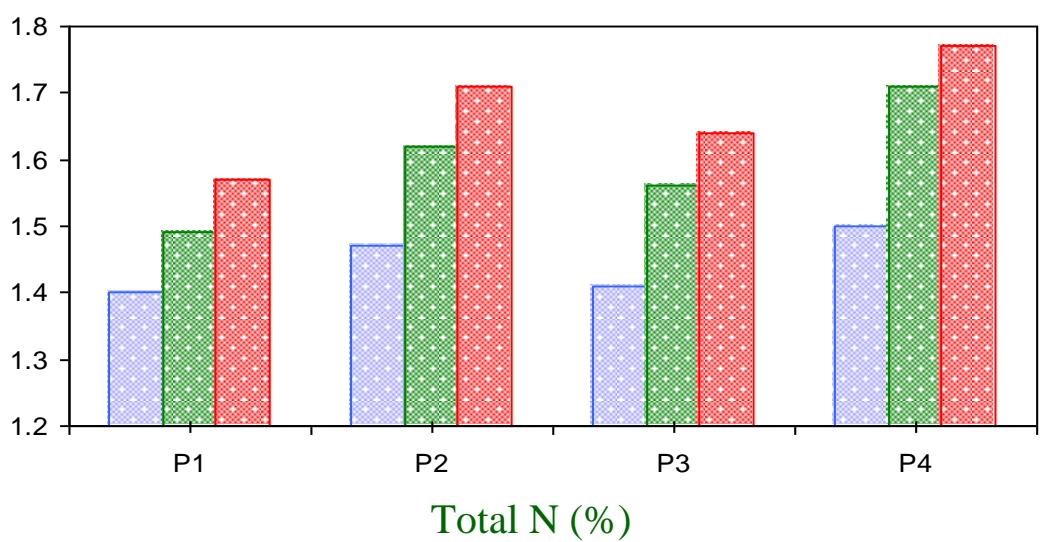

Fig.2 Total nitrogen content of organics at different stages of decomposition
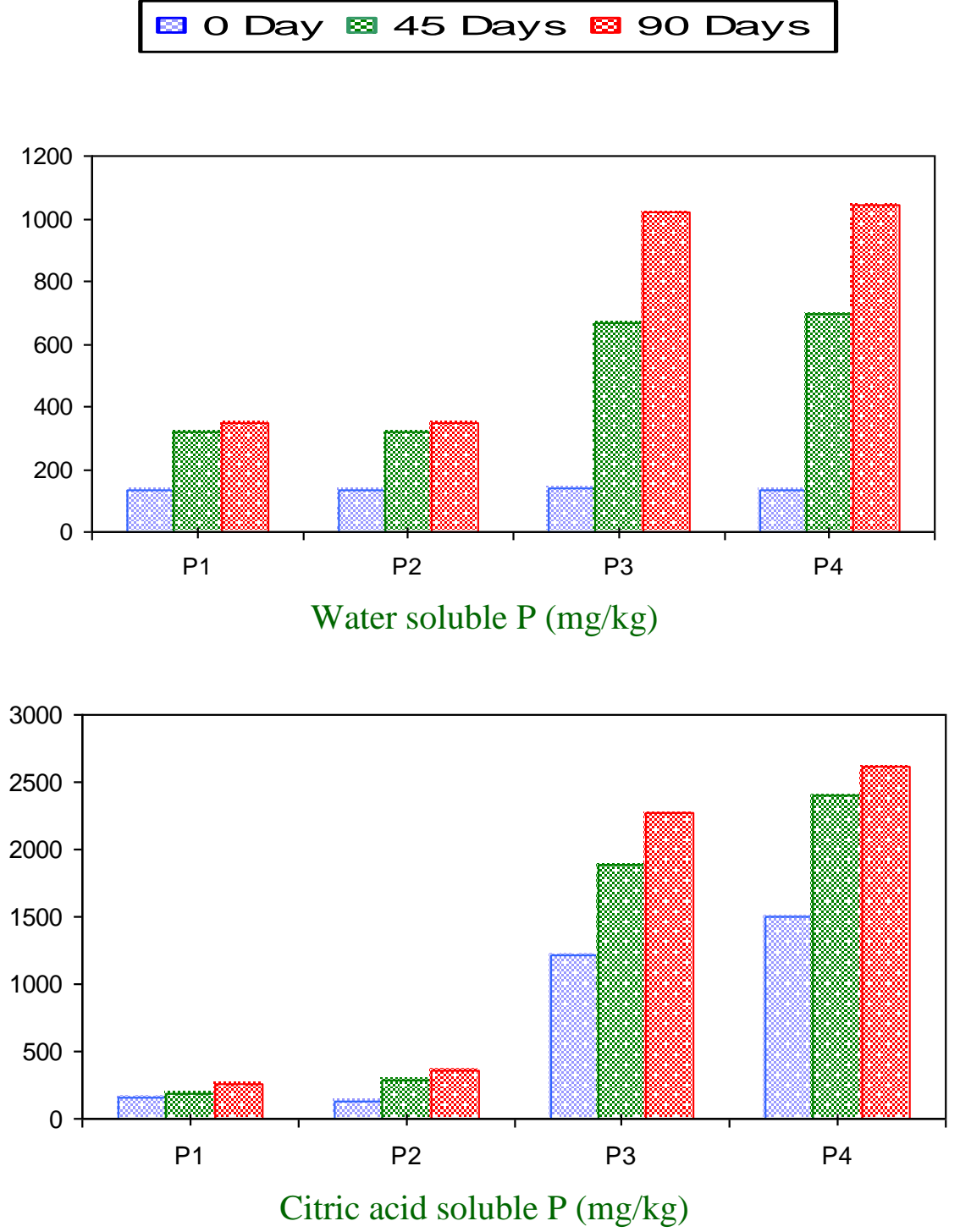


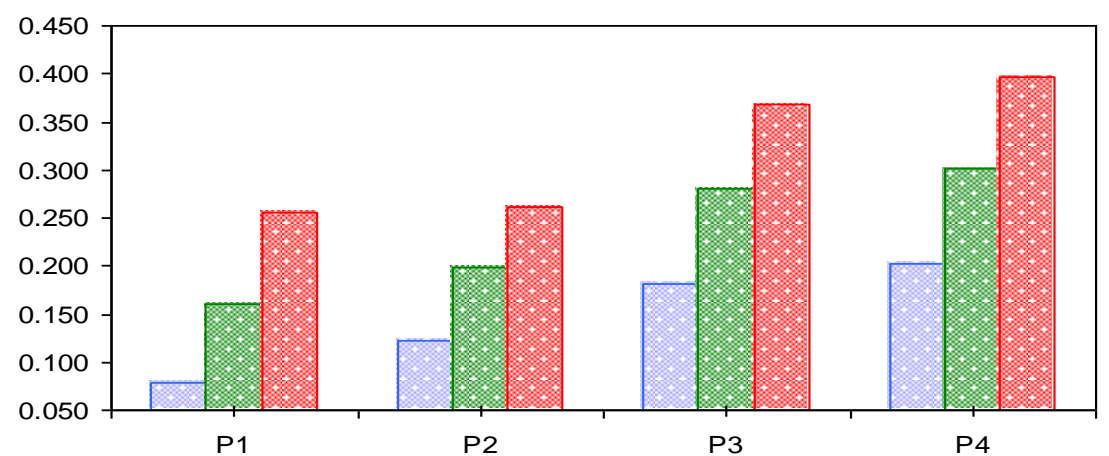

Sodium bicarbonate extractable P $(\%)$

$\begin{array}{ll}\text { PRODUCTS } & \\ \text { P1: FYM } & \text { P2: Compost } \\ \text { P3: P-enriched FYM } & \text { P4: P-enriched compost }\end{array}$

Fig.3 Phosphorus content of organics at different stages of decomposition

응 Day 45 Days 990 Days
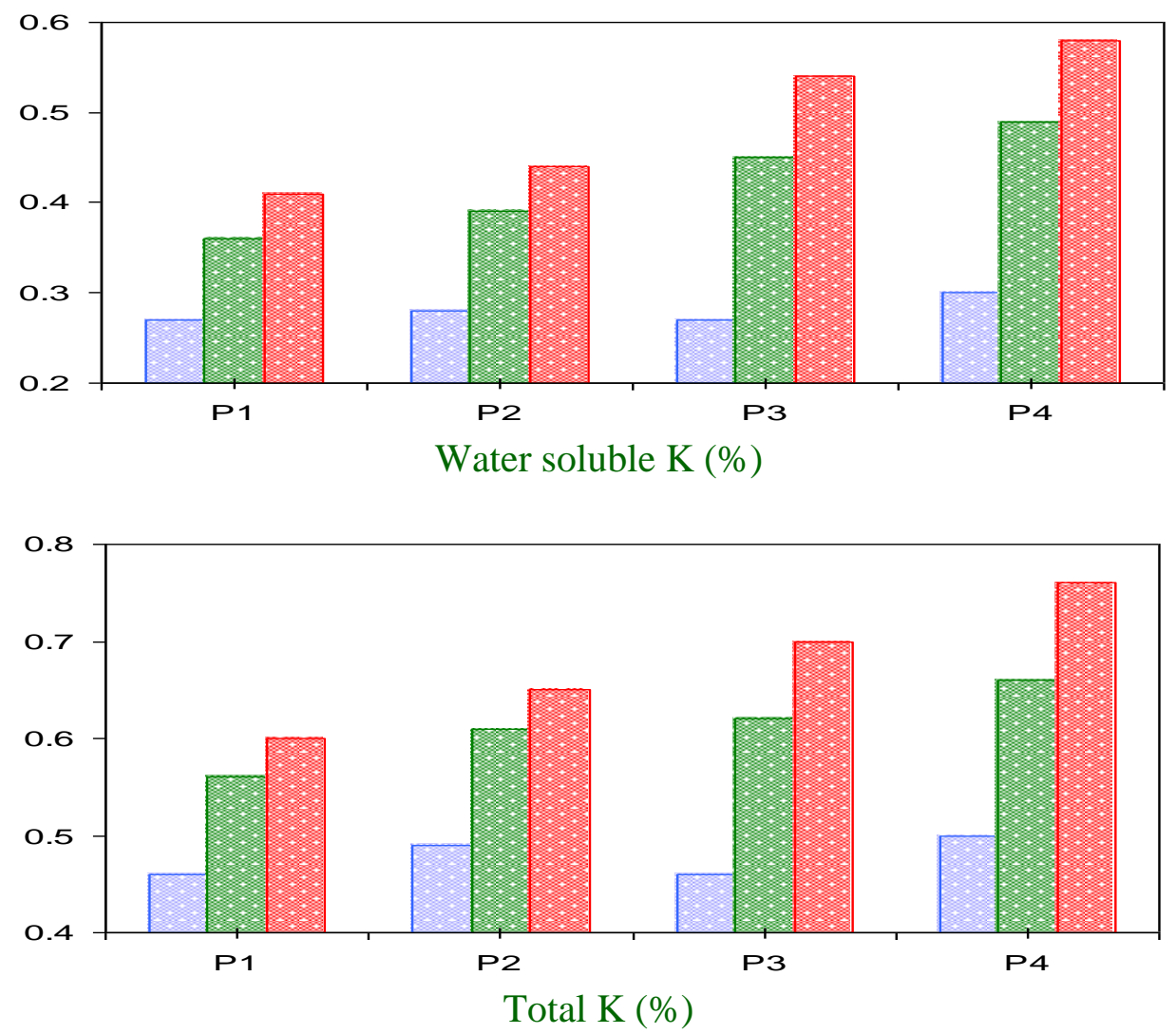

PRODUCTS

$\begin{array}{ll}\text { P1: FYM } & \text { P2: Compost } \\ \text { P3: P-enriched FYM } & \text { P4: P-enriched compost }\end{array}$

Fig.5 Potassium content of organics at different stages of decomposition 
음 Day 45 Days 890 Days
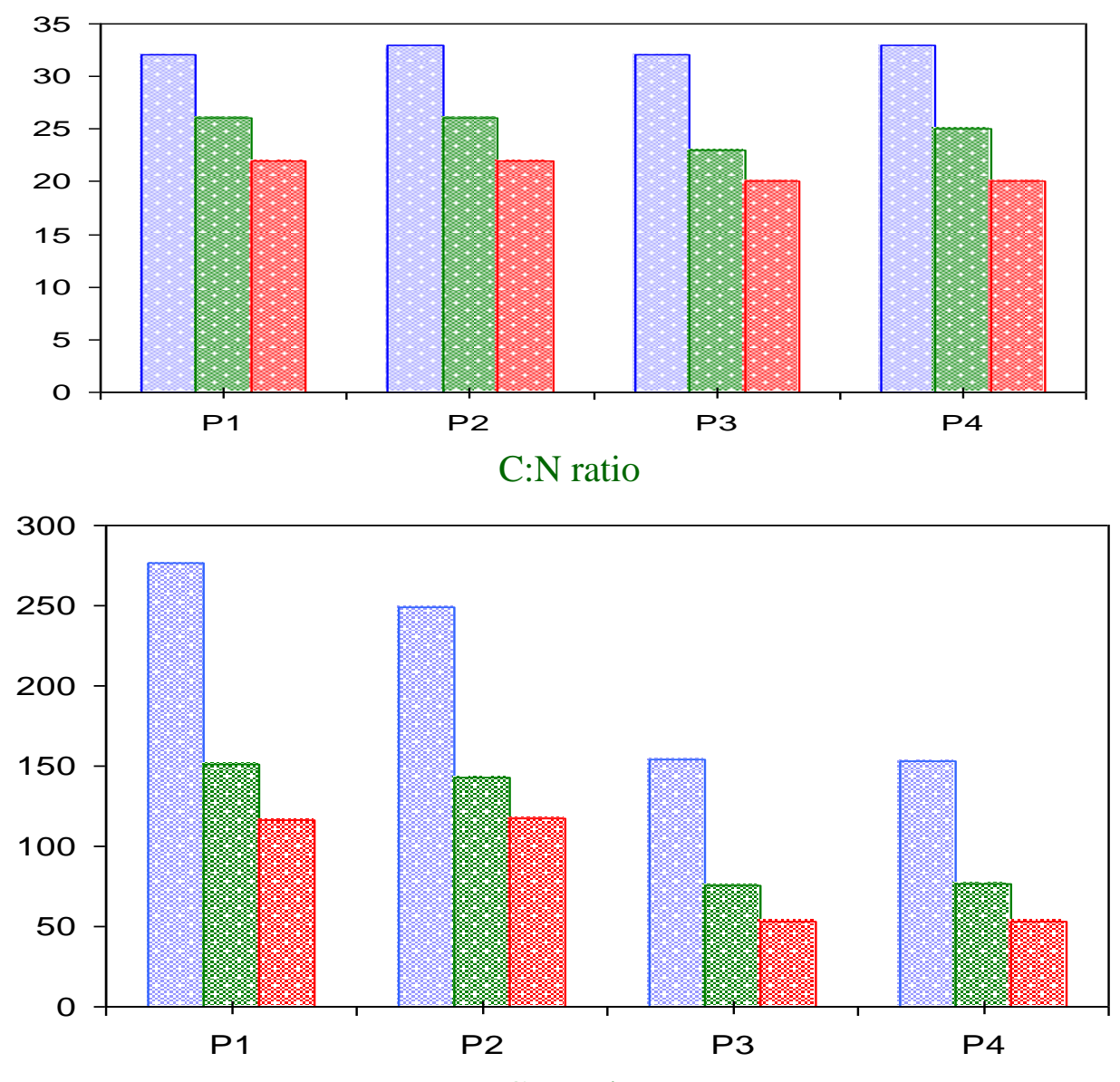

$\mathrm{C}: \mathrm{P}$ ratio

PRODUCTS

P1 : FYM

P3 : P-enriched FYM
P2 : Compost

P4 : P-enriched compost

Fig.6 C:N and C:P ratio of organics at different stages of decomposition

Results indicated that enriched manures recorded higher content of nutrient elements $(\mathrm{N}, \mathrm{P}$ and $\mathrm{K})$. Thus, enrichment of organic manures using FYM or compost and lowgrade rock phosphate is a step forward to organic farming: an alternative and viable technique which improves soil health and provides an alternate source of phosphatic fertilizers.

\section{References}

Bhardwaj, K.K.R. 1995. Wealth from Wastes. 115-136 p. Sunil Khanna and Krishna Mohan (Ed.). Tata Energy Research Institute, New Delhi.

Black, C.A. 1965. Methods of Soil Analysis Part-1 and 2. American Society of Agronomy. Madison (Wisconsin), USA. 
Chien, S.H. 1979. Dissolution of phosphate rock in acid soils as influenced by nitrogen and potassium fertilizers. Soil Science 127: 371-376.

Gaur, A.C. 1999. Microbial Technology for composting of agricultural residues by improved methods. Directorate of Information and Publications of Agriculture. Indian Council of Agricultural Research, New Delhi.

Havlin, J.L., Beaton, J.D., Tisdale, S.L. and Nelson, W.L. 2003. Soil Fertility and Fertilizers: An introduction to nutrient management. 184 p. Pearson Education (Singapore) Pte Ltd., Indian Branch, 482 FIE Patparganj, Delhi (India).

Manna, M.C., Hajra, J.N. and Singh, A.B. 2001. Comparative effectiveness of enriched phosphocompost and chemical fertilizer on crop yields and soil biological activity in an alluvial soil. Indian Journal of Agricultural Research
35(4): 247-250.

Mathur, B.S. and Devnath, D. 1983. Studies on phosphorus in compost charged with rock phosphate. Journal of the Indian Society of Soil Science 31: 545-548.

Mishra, B., Sharma, A., Roy, N.K., Shahi, D.K. and Lal, J.K. 2001. Nutrient status of phospho- compost and its effect on maize (Zea mays) - Wheat (Triticum aestivum) cropping system as a source of phosphorus in acid Alfisol of Ranchi, Jharkhand. Indian Journal of Agricultural Sciences. 71(12): 749-751.

Mishra, M.M., Kapoor, K.K. and Yadav, K.S. 1982. Effect of compost enriched with Mussorie rock phosphate on crop yield. Indian Journal of Agricultural Sciences 52: 674-678.

Singh, C.P. and Amberger, A. 1990. Humic substances in straw compost with rock phosphate. Biological Wastes 31: 165174.

\section{How to cite this article:}

Kanika Baghla, Jain Praveen Kumar, Chopra Pankaj and Tammana. 2020. Studies on Manurial Quality of Compost Enriched with Rock Phosphate. Int.J.Curr.Microbiol.App.Sci. 9(04): 17571765. doi: https://doi.org/10.20546/ijcmas.2020.904.206 